\title{
PENGARUH PEMBERIAN SNACK BAR KEDELAI TERHADAP KADAR KOLESTEROL LDL DAN HDL WANITA HIPERKOLESTEROLEMIA
}

\author{
Aryanti Setyaningsih, Adriyan Pramono") \\ Program Studi Ilmu Gizi Fakultas Kedokteran Universitas Diponegoro \\ Jl.Dr.Sutomo No.18, Semarang, Telp (024) 8453708, Email : gizifk@ undip.ac.id
}

\begin{abstract}
Background : Soybean (black and yellow) contains isoflavones and anthocyanins that may influence the decrease of LDL cholesterol and increase of HDL cholesterol, and also purple sweet potato contain anthocyanins too. This study aims to determined the effect of purple sweet potato and soybeans snack bar on LDL and HDL cholesterol levels in women with hypercholesterolemia.

Methods : This was a quasi-experimental study with pre-post test control group design. The subjects were women with LDL cholesterol levels > $130 \mathrm{mg} / \mathrm{dl}$ and HDL cholesterol levels $<50 \mathrm{mg} / \mathrm{dl}$ and divided into 3 groups. Control group was not consume the snack bar, group 1 consume black soybean snack bar, and group 2 consume yelow soybean snack bar. Snack bar is given to subjects by 2 snack time (40g each) for 28 days. During the intervention, the intake data collected by using 24 hours Food Recall. LDL and HDL cholesterol levels were measured before and after intervention. Data were analyzed using paired t- test, fisher 's exact, and annova.

Results : Consumption of black soybean snack bar can lower LDL cholesterol by 6,47 \% while yellow soybeans snack bar can lower LDL cholesterol by 13,02\%. The level of LDL in control group increased by 2,25\%. However there weren't an increased in HDL cholesterol levels in both treatment groups and control group. There are no significant difference in LDL levels between group 1 and control. It decreased only in the group of yellow soybeans snack bar $(p=0,049)$.

Conclusion : The decrease in LDL cholesterol levels due to consumption of soybean snack bars, especially the most yellow soybean snack bars lowers LDL cholesterol levels by consumption $80 \mathrm{~g} /$ day for 28 days.

Keywords: Purple sweet potato; black soybean; yellow soybeans; snack bar; LDL cholesterol level; HDL cholesterol level; hypercholesterolemia
\end{abstract}

\begin{abstract}
ABSTRAK
Latar Belakang: Kedelai (hitam dan kuning) mengandung antosianin dan isoflavon yang dapat menurunkan kadar kolesterol LDL dan meningkatkan kadar kolesterol HDL. Selain itu ubi jalar ungu juga mengadung antosianin. Penelitian ini bertujuan mengetahui pengaruh pemberian snack bar ubi jalar ungu dicampur kedelai terhadap kadar kolesterol LDL dan HDL pada wanita hiperkolesterolemia.

Metode: Desain peneitian ini adalah quasi-experimental dengan pre-post test control group design. Subyek penelitian adalah wanita dewasa dengan kadar kolesterol $L D L>130 \mathrm{mg} / \mathrm{dl}$ dan kadar kolesterol $\mathrm{HDL}<50 \mathrm{mg} / \mathrm{dl}$ yang dibagi menjadi 3 kelompok. Kelompok kontrol tidak diberi snack bar, kelompok 1 diberikan snack bar kedelai hitam, dan kelompok 2 diberikan snack bar kedelai kuning. Snack bar yang diberikan sebanyak 2 buah snack (40g) selama 28 hari. Asupan makan dipantau dengan metode food recall 24 jam. Kadar kolesterol LDL dan HDL diukur sebelum dan sesudah intervensi. Data yang diperoleh dianalaisis menggunakan paired t-test, fisher's exact, dan annova .

Hasil: Terdapat penurunan kadar kolesterol LDL 6,47\% pada konsumsi snack bar kedelai hitam dan penurunan kadar kolesterol LDL 13,02\% pada konsumsi snack bar kedelai kuning. Pada kelompok kontrol terjadi peningkatan kadar kolesterol LDL sebesar 2,25\%. Tidak terdapat peningkatan kadar kolesterol HDL pada kedua kelompok perlakuan dan kontrol. Ada perbedaan penurunan kadar LDL hanya pada kelompok snack bar kedelai kuning $(p=0,049)$.

Kesimpulan: Penurunan kadar kolesterol LDL karena pemberian snack bar kedelai, terutama snack bar kedelai kuning yang paling banyak menurunkan kadar kolesterol LDL dengan pemberian 80 g/hari selama 28 hari.

Kata kunci: ubi jalar ungu; kedelai hitam; kedelai kuning; snack bar; kolesterol LDL; kolesterol HDL; hiperkolesterolemia

\section{PENDAHULUAN}

Hiperkolesterolemia merupakan keadaan terjadinya gangguan metabolisme lemak yang menyebabkan kadar kolesterol total dan LDL meningkat sedangkan kadar kolesterol HDL

mengalami penurunan ${ }^{1,2}$. Pola makan dengan asupan tinggi lemak jenuh dan kolesterol serta rendahnya aktivitas fisik merupakan faktor risiko yang menyebabkan terjadinya hiperkolesterolemia ${ }^{2,3}$. Menurunkan dan menjaga
\end{abstract}


kadar kolesterol LDL dalam batas aman dapat dilakukan dengan mengurangi asupan lemak jenuh kurang dari $7 \%$ total energi dan kolesterol kurang dari $200 \mathrm{mg}$ per hari serta mengonsumsi bahan makanan yang memiliki efek hipokolesterolemik, salah satunya kedelai ${ }^{2,3,4}$.

Penelitian mengenai makanan berbasis kedelai dengan kandungan isoflavon sebanyak 10 mg dan 73 mg selama 28 hari kepada subyek dengan hiperlipidemia dapat menurunkan kadar kolesterol LDL sebesar $7,52 \%$ dan $9,01 \%^{5}$. Kandungan senyawa bioaktif dalam kedelai seperti isoflavon dan antosianin dapat menurunkan risiko terjadinya penyakit jantung dan pembuluh darah melalui mekanisme pengaturan metabolisme kolesterol, yaitu meningkatkan sekresi asam empedu, menurunkan absorbsi kolesterol di usus halus, dan berperan sebagai antioksidan eksogen. Isoflavon yang terdapat pada kedelai adalah daidzein dan genistein berperan sebagai kardioprotektif karena memiliki efek seperti estrogen dan dapat berikatan dengan reseptor estrogen $^{5,6,7,8}$.

Kedelai yang banyak dimanfaatkan sebagai bahan olahan adalah kedelai kuning (Glycine max), sedangkan kedelai hitam (Glycine soja) hanya terbatas pada bahan baku kecap padahal kandungan antosianin yang terdapat pada kulit kedelai hitam dan protein lebih tinggi dibandingkan kedelai kuning ${ }^{9,10}$. Kedelai hitam berdasarkan penelitian oleh Takahashi et al, diketahui memiliki antosianin yang lebih tinggi, yaitu $29 \pm 0,56 \mathrm{mg} / \mathrm{g}$ dibandingkan kedelai kuning, $0,45 \pm 0,02 \mathrm{mg} / \mathrm{g}^{10}$. Antosianin yang terdapat pada kulit kedelai hitam, cyanidin-3-glucoside, berperan sebagai antioksidan sehingga dapat menghambat oksidasi kolesterol LDL ${ }^{9,11}$. Pemberian kedelai kuning, kedelai hitam, dan sword beans terhadap kadar kolesterol darah pada tikus dengan pakan tinggi kolesterol selama 10 minggu dapat menurunkan kadar kolesterol LDL, terutama pada tikus yang diberi intervensi kedelai hitam, yaitu sebesar 3,58 $\pm 0,65 \mathrm{mg} / \mathrm{dl}$. Tetapi peningkatan kadar HDL pada tikus yang diberi kedelai hitam tidak signifikan dibanding dengan pemberian kedelai kuning dan sword bean'.

Antosianin termasuk dalam kelompok polifenol subkelas flavonoid dan dapat berperan sebagai antioksidan pada beberapa jenis bahan pangan seperti pada kedelai hitam dan ubi jalar ungu $^{9,12}$. Pemberian ekstrak air umbi ubi jalar ungu terhadap penurunan kolesterol pada 20 ekor kelinci dengan pemberian $3 \mathrm{ml} /$ hari ekstrak air umbi ubi jalar ungu yang mengandung antosianin sebanyak
$146 \mathrm{mg} / \mathrm{ml}$, selama 90 hari menunjukkan penurunan kadar LDL darah sebesar $33 \%$ dan peningkatan HDL sebesar $1,2 \%{ }^{13}$.

Kedelai dan ubi jalar ungu merupakan bahan pangan yang biasa dikonsumsi dan dijadikan berbagai olahan pangan. Efek penurunan kadar kolesterol LDL dan HDL dari kedua bahan pangan tersebut sudah diketahui secara terpisah, sedangkan dalam bentuk satu produk makanan belum pernah diketahui efeknya. Kedua bahan pangan tersebut dapat dijadikan olahan pangan seperti snack bar. Pemilihan jenis snack bar dikarenakan dapat dijadikan alternatif makanan selingan yang menyumbang $\pm 10 \%$ dari kebutuhan energi per hari serta bernilai gizi tinggi ${ }^{1}$. Hal inilah yang mendasari dilakukannya penelitian untuk mengetahui pengaruh pemberian snack bar kedelai terhadap kadar kolesterol LDL dan HDL pada wanita hiperkolesterolemia.

\section{METODE PENELITIAN}

Jenis penelitian ini adalah quasi experimental dengan rancangan pre-post control group design. Penelitian dilakukan di Sekretariat Daerah Provinsi Jawa Tengah pada bulan AgustusOktober 2013. Subyek penelitian adalah wanita yang memenuhi kriteria inklusi diambil secara consecutive sampling. Kriteria inklusi subyek penelitian antara lain bersedia menjadi subyek penelitian dengan mengisi informed consent, belum mengalami menopause, kadar kolesterol LDL $>130 \mathrm{mg} / \mathrm{dl}$ dan kadar kolesterol $\mathrm{HDL}<50$ $\mathrm{mg} / \mathrm{dl}$, tidak sedang mengkonsumsi obat antihiperlipidemia dan tidak dalam keadaan sakit atau perawatan dokter, serta tidak dalam keadaan hamil atau menyusui.

Perhitungan besar subyek penelitian yang diperoleh menggunakan rumus uji hipotesis terhadap rerata dua populasi independen dan dibutuhkan sebanyak 24 subyek yang dibagi secara acak. Dalam penelitian ini diambil sebanyak 30 subyek untuk mengantisipasi drop out karena jangka waktu intervensi yang lama. Penelitian ini digunakan tiga kelompok perlakuan yaitu kelompok kontrol (K), kelompok snack bar kedelai hitam (P1), kelompok snack bar kedelai kuning (P2) yang masing-masing kelompok terdiri dari 10 subyek. Kelompok kontrol tidak diberikan snack bar. Kelompok perlakuan diberikan snack bar 1 kali sehari dengan jumlah porsi sebanyak 2 buah dengan berat $40 \mathrm{~g} /$ snack bar untuk snack pagi dan sore selama 28 hari.

Pembuatan snack bar melalui proses pemanggangan dengan perbandingan komposisi 
kedelai (hitam atau kuning) dan ubi jalar ungu 40:60 serta komposisi ubi jalar ungu $80 \%$ merupakan ubi jalar ungu yang telah dikukus dan $20 \%$ dalam bentuk tepung. Adonan yang telah matang dipotong sebanyak 40 g. Penggunaan tepung ubi jalar ungu bertujuan untuk memadatkan adonan snack bar. Resep adonan snack bar ini merupakan resep inovasi ITP.

Pemberian snack bar dilakukan selama 28 hari. Pada ketiga kelompok tidak diberikan pengaturan makan khusus atau tidak merubah pola makan subyek. Pencatatan asupan makan dilakukan menggunakan metode recall 24 jam. Pada hari ke-29 dilakukan pengambilan darah kembali untuk mengetahui perubahan kadar kolesterol LDL dan HDL setelah diberikan intervensi.

Terdapat subyek yang drop out dalam penelitian ini karena mengundurkan diri pada awal penelitian sebanyak 2 orang, tidak patuh terhadap intervensi yang diberikan sebanyak 3 orang dan tidak hadir saat pengambilan darah terakhir 1 orang.

Kadar kolesterol LDL dan HDL dianalisis dengan pemeriksaan laboratorium menggunakan metode perhitungan dan phosphotungstic parcipitation. Darah diambil oleh petugas laboratorium setelah subyek berpuasa selama \pm 10 jam. Sementara data asupan makan subyek dianalisis menggunakan program nutrisurvey 2005. Karakteristik subyek dianalisis menggunakan analisis deskriptif. Uji normalitas menggunakan uji Shapiro-Wilk. Perbedaan rerata kadar kolesterol LDL dan HDL sebelum dan sesudah intervensi serta asupan zat gizi sebelum dan selama intervensi diuji menggunakan paired $t$ test. Uji Annova digunakan untuk melihat perbedaan perubahan asupan sebelum dan selama penelitian.

\section{HASIL PENELITIAN}

Penelitian dilaksanakan di Kantor Sekretariat Daerah (SETDA) Provinsi Jawa Tengah pada bulan Agustus-Oktober 2013. Berdasarkan skrining terdapat 30 subyek wanita yang memenuhi kriteria inklusi kemudian dibagi menjadi 3 kelompok. Selama penelitian terdapat 5 subyek dari kelompok perlakuan yang mengalami drop out karena tidak mematuhi prosedur penelitian dan 1 subyek dari kelompok kontrol yang tidak hadir saat pengambilan darah terakhir. Jumlah akhir subyek penelitian adalah 24 orang.

Karakteristik subyek meliputi tingkat pendidikan, kategori IMT, kadar kolesterol LDL dan HDL sebelum penelitian tersaji pada tabel 1 .

Tabel 1. Deskripsi Karakteristik Tiap Kelompok

\begin{tabular}{lccc}
\hline \multirow{2}{*}{ Karakteristik subyek } & $\mathbf{K}$ & $\mathbf{P 1}$ & P2 \\
\cline { 2 - 4 } & $\mathbf{n}(\mathbf{\%})$ & $\mathbf{n}(\mathbf{\%})$ & $\mathbf{n}(\mathbf{\%})$ \\
\hline Indeks Massa Tubuh & & & \\
$\quad$ Normal $(18,5-22,9)$ & $2(22,2 \%)$ & $2(22,2 \%)$ & $1(16,7 \%)$ \\
Overweight $(23-24,9)$ & $4(44,4 \%)$ & $2(22,2 \%)$ & $1(16,7 \%)$ \\
Obesitas I $(25-29,9)$ & $1(11,1 \%)$ & $3(33,3 \%)$ & $3(50 \%)$ \\
Obesitas II ( $\geq 30)$ & $2(22,2 \%)$ & $2(22,2 \%)$ & $1(16,7 \%)$ \\
\hline Pendidikan & & & \\
Tamat SMA & $2(22,2 \%)$ & $1(11,1 \%)$ & \\
Tamat Perguruan Tinggi & $7(77,8 \%)$ & $8(88,9 \%)$ & $6(100 \%)$ \\
\hline
\end{tabular}

Sebagian besar subyek dalam kelompok kontrol $(44,4 \%)$ memiliki kategori IMT overweight. Kedua kelompok perlakuan sebagian besar memiliki kategori IMT obesitas 1 . Pendidikan subyek penelitian sebagian besar adalah tamat perguruan tinggi.
Kadar Kolesterol LDL dan HDL pada Awal Penelitian

Uji beda kolesterol LDL dan HDL awal antar kelompok dilakukan untuk mengetahui homogenitas subyek sebelum intervensi.

Tabel 2. Kadar Kolesterol LDL dan HDL Subyek pada Awal Penelitian

\begin{tabular}{ccccc}
\hline Karakteristik & Kontrol $(\mathrm{n}=9)$ & Perlakuan & Perlakuan & $\mathbf{p}^{1}$ \\
\hline
\end{tabular}




\begin{tabular}{lcccc}
\hline & \multicolumn{3}{c}{$\mathbf{1}(\mathbf{n}=9)$} & $\mathbf{2}(\mathbf{n}=\mathbf{6})$ \\
\cline { 2 - 4 } & Rerata \pm SB & Rerata \pm SB & Rerata \pm SB & \\
\hline Kol. LDL $(\mathrm{mg} / \mathrm{dl})$ & $160,2 \pm 18,49$ & $159,1 \pm 27,99$ & $152,6 \pm 17,03$ & 0,795 \\
\hline Kol. HDL $(\mathrm{mg} / \mathrm{dl})$ & $48,67 \pm 7,01$ & $49,33 \pm 2,44$ & $47,16 \pm 8,01$ & 0,792 \\
\hline
\end{tabular}

Ket : 1 = uji Annova, Perlakuan 1= kelompok snack bar kedelai hitam, Perlakuan 2= kelompok snack bar kedelai kuning

Tabel 2 menunjukkan tidak ada perbedaan kadar kolesterol LDL dan HDL sebelum intervensi antar ketiga kelompok ( $\mathrm{p}>0,05)$.

\section{Perbedaan dan Perubahan Asupan Makan} Sebelum dan Selama Intervensi
Asupan makan subyek yang didapatkan selama penelitian yaitu meliputi energi, protein, lemak, karbohidrat, serat, dan kolesterol.

Tabel 3. Asupan Makan Subyek Selama Intervensi

\begin{tabular}{|c|c|c|c|c|}
\hline \multirow{2}{*}{$\begin{array}{l}\text { Asupan Zat } \\
\text { Gizi }\end{array}$} & $\begin{array}{c}\begin{array}{c}\text { Kontrol } \\
(\mathbf{n}=9)\end{array} \\
\end{array}$ & $\begin{array}{c}\text { Perlakuan } 1 \\
(n=9)\end{array}$ & $\begin{array}{c}\begin{array}{c}\text { Perlakuan } 2 \\
(n=6)\end{array} \\
\end{array}$ & \multirow[t]{2}{*}{$\mathbf{p}^{1}$} \\
\hline & Rerata \pm SB & Rerata \pm SB & Rerata \pm SB & \\
\hline \multicolumn{5}{|l|}{ Energi (kkal) } \\
\hline Pre & $1531 \pm 169$ & $1578 \pm 280$ & $1367 \pm 158$ & 0,191 \\
\hline Intervensi & $1397 \pm 242$ & $1374 \pm 145$ & $1325 \pm 144$ & 0,768 \\
\hline$\Delta$ & $-133 \pm 176$ & $-203 \pm 259$ & $-41 \pm 237$ & 0,412 \\
\hline $\mathrm{P}$ & 0,053 & 0,046 & 0,683 & \\
\hline \multicolumn{5}{|l|}{ Protein } \\
\hline Pre & $56,5 \pm 15$ & $52,8 \pm 16,3$ & $42,4 \pm 13,1$ & 0,222 \\
\hline Intervensi & $46,4 \pm 10,3$ & $49,4 \pm 6,5$ & $46,1 \pm 9,7$ & 0,718 \\
\hline$\Delta$ & $-10,08 \pm 15,4$ & $-3,4 \pm 15,5$ & $3,71 \pm 6,4$ & 0,190 \\
\hline $\mathrm{P}$ & 0,085 & 0,526 & 0,213 & \\
\hline \multicolumn{5}{|l|}{ Lemak (g) } \\
\hline Pre & $50,2 \pm 22,8$ & $50,9 \pm 32,7$ & $34,7 \pm 9,1$ & 0,418 \\
\hline Intervensi & $44,5 \pm 11,7$ & $43,9 \pm 5,7$ & $41,1 \pm 7.3$ & 0,746 \\
\hline$\Delta$ & $-5,67 \pm 27,7$ & $-7,01 \pm 29,9$ & $6,41 \pm 13,7$ & 0,587 \\
\hline $\mathrm{P}$ & 0,556 & 0,502 & 0,304 & \\
\hline \multicolumn{5}{|l|}{ Karbohidrat (g) } \\
\hline Pre & $202 \pm 50$ & $232 \pm 48$ & $224 \pm 54$ & 0,440 \\
\hline Intervensi & $205 \pm 42$ & $197 \pm 28$ & $195 \pm 17$ & 0,818 \\
\hline$\Delta$ & $3,09 \pm 58,51$ & $-34 \pm 48$ & $-28 \pm 55$ & 0,311 \\
\hline $\mathrm{P}$ & 0,878 & 0,061 & 0,263 & \\
\hline \multicolumn{5}{|l|}{ Serat (g) } \\
\hline Pre & $13 \pm 4$ & $14,6 \pm 5,6$ & $11,7 \pm 6,9$ & 0,589 \\
\hline Intervensi & $9,9 \pm 3,3$ & $10,6 \pm 2,9$ & $12,4 \pm 3,7$ & 0,373 \\
\hline$\Delta$ & $-3,05 \pm 5,59$ & $-4,04 \pm 7,5$ & $0,74 \pm 5,4$ & 0,359 \\
\hline $\mathrm{P}$ & 0,141 & 0,147 & 0,748 & \\
\hline \multicolumn{5}{|l|}{ Kolesterol (mg) } \\
\hline Pre & $180 \pm 115$ & $168 \pm 127$ & $110 \pm 71$ & 0,474 \\
\hline Intervensi & $167 \pm 86$ & $129 \pm 61$ & $126 \pm 46$ & 0,423 \\
\hline$\Delta$ & $-13,31 \pm 145,1$ & $-38 \pm 121$ & $16 \pm 68$ & 0,700 \\
\hline $\mathrm{P}$ & 0,791 & 0,372 & 0,587 & \\
\hline
\end{tabular}

Ket : 1 = uji Annova, Perlakuan 1= kelompok snack bar kedelai hitam, Perlakuan 2= kelompok snack bar kedelai kuning

Tabel 3 menunjukkan tidak terdapat perbedaan rerata asupan energi, protein lemak, karbohidrat, kolesterol dan serat sebelum dan selama intervensi pada ketiga kelompok ( $\mathrm{p}>0,05)$. Tetapi terdapat perbedaan rerata asupan energi pada kelompok $1 \quad(\mathrm{p}=0,046)$. Rerata perubahan 
asupan zat gizi menunjukkan tidak ada perbedaan antara kelompok perlakuan dan kontrol $(\mathrm{p}>0,05)$.
Perbedaan kadar LDL dan HDL subyek sebelum dan setelah intervensi disajikan pada Grafik 1.

Perbedaan Kadar I
Sesudah Intervensi

Grafik 1. Perubahan Kadar Kolesterol LDL Sebelum dan Sesudah Intervensi

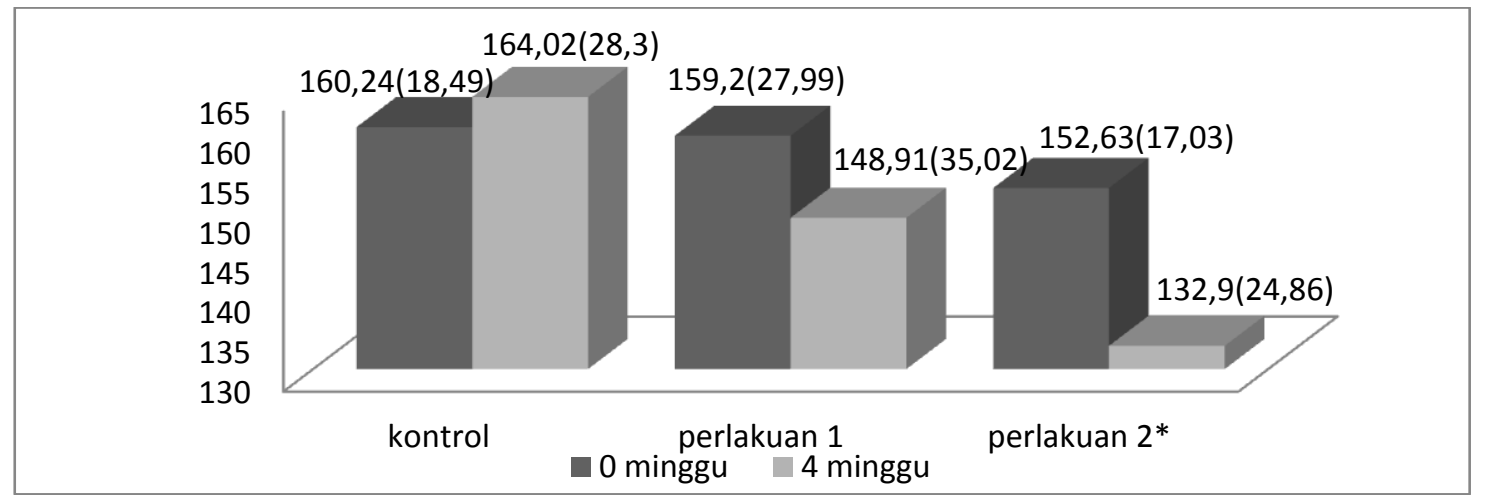

Ket: *= Paired sample $\mathrm{t}$-test, *Signifikan $\mathrm{p}<0,05$, Perlakuan $1=$ kelompok snack bar kedelai hitam, Perlakuan 2= kelompok snack bar kedelai kuning

Pada grafik 1, terdapat penurunan kadar kolesterol LDL sebelum dan sesudah intervensi pada kelompok perlakuan 1 dan perlakuan 2 sebesar 10,27 mg (6,47\%) dan 19,73 mg (13,02\%). Penurunan yang bermakna hanya terjadi pada kelompok perlakuan 2 atau yang diberikan snack bar kedelai kuning $(\mathrm{p}=0,049)$. Sedangkan pada kelompok kontrol mengalami kenaikan kadar kolesterol LDL sebesar 3,77 mg (2,25\%).

Grafik 2. Perubahan Kadar Kolesterol HDL Sebelum dan Sesudah Intervensi

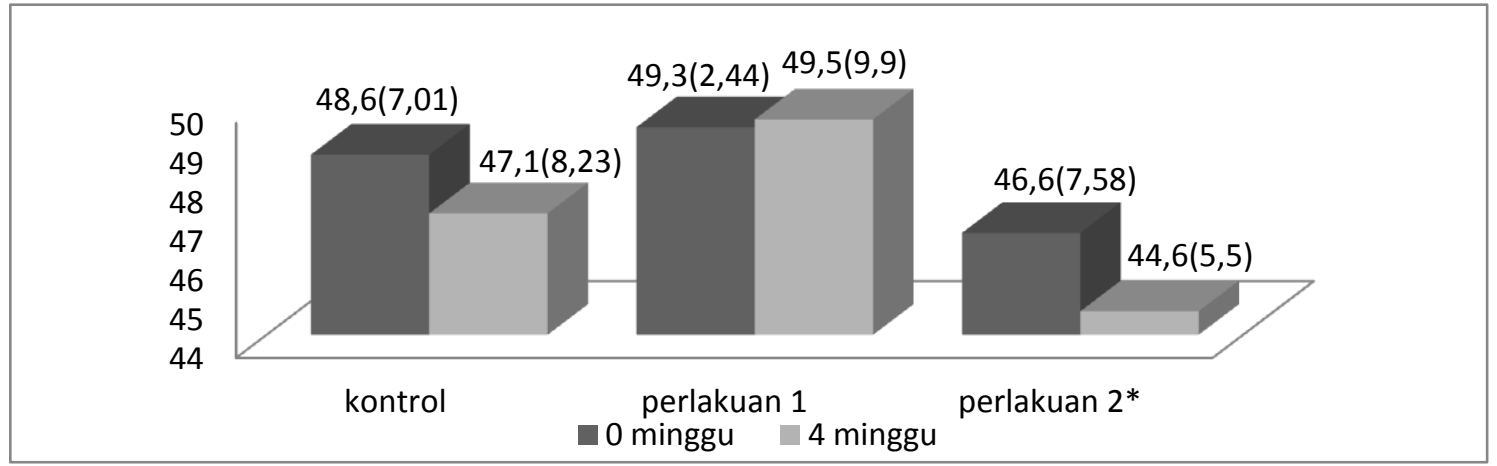

Ket: Paired sample $\mathrm{t}$-test, Perlakuan 1= kelompok snack bar kedelai hitam, Perlakuan 2= kelompok snack bar kedelai kuning

Pada grafik 2, terdapat penurunan kadar kolesterol HDL sebelum dan sesudah intervensi pada kelompok kontrol dan perlakuan 2. Terdapat kenaikan sebesar $0,22 \mathrm{mg}$ pada kelompok perlakuan 1 atau kelompok yang diberikan snack bar kedelai hitam.

\section{PEMBAHASAN}

Subyek dalam penelitian ini berjenis kelamin wanita usia pre-menopause atau usia produktif. Alasan dipilihnya wanita usia premenopause sebagai subyek karena meningkatnya kadar kolesterol LDL dan menurunnya kadar kolesterol HDL tidak dipengaruhi oleh berkurangnya hormon estrogen serta dalam menurunkan kadar kolesterol LDL lebih cepat pada wanita usia pre-menopause ${ }^{14}$. Pada wanita menopause terjadi perubahan fungsi ovarium yang menyebabkan berkurangnya hormon estrogen, perubahan metabolisme karbohidrat dan lemak, perubahan kadar kolesterol dalam darah (kolesterol total, LDL, dan trigliserida meningkat serta kolesterol HDL menurun), dan perubahan distribusi lemak tubuh. Estrogen berperan dalam metabolisme lemak dengan meregulasi lipoprotein 
lipase pada jaringan adiposa dan hepatosit serta menurunkan sintesis lipase hepatik ${ }^{3,15}$.

Sebagian subyek besar penelitian termasuk dalam kategori obesitas I (IMT 25-29,9 kg/m²) dan overweight (IMT 23-24,9 $\mathrm{kg} / \mathrm{m}^{2}$ ). Hasil recall asupan energi, protein, lemak, karbohidrat, serat dan kolesterol sebelum dan selama intervensi tidak terdapat perbedaan bermakna antar ketiga kelompok. Rata-rata asupan lemak pada ketiga kelompok sebelum penelitian lebih tinggi dibandingkan selama penelitian. NCEP-ATP III (National Cholesterol Education Program) merekomendasikan $30 \%$ asupan lemak, $7 \%$ asupan lemak jenuh dan $1 \%$ asupan lemak trans dari total energi, serta $200 \mathrm{mg} / \mathrm{hari}$ asupan kolesterol untuk diet rendah kolesterol ${ }^{3}$. Asupan lemak berpengaruh terhadap asupan kolesterol. Rata-rata asupan kolesterol sebelum intervensi pada kelompok kontrol, perlakuan 1, dan perlakuan 2 berturut-turut sebesar $180 \mathrm{mg}$, perlakuan $168 \mathrm{mg}$, dan $110 \mathrm{mg}$. Setelah intervensi terjadi penurunan asupan kolesterol pada kelompok kontrol dan perlakuan 1 menjadi $167 \mathrm{mg}$ dan $126 \mathrm{mg}$. Sedangkan pada kelompok perlakuan 2 terjadi peningkatan rata-rata asupan kolesterol sebesar 126 mg. Asupan kolesterol dan lemak tak jenuh dapat meningkatkan kadar kolesterol LDL dengan menurunkan sintesis dan aktivitas reseptor $\mathrm{LDL}^{1}$.

Peningkatan asupan lemak merupakan faktor risiko obesitas ${ }^{1}$. Adanya obesitas menyebabkan meningkatnya jaringan adiposa dan resisten insulin yang menyebabkan adanya gangguan metabolisme lemak di hati terganggu sehingga melepaskan banyak asam lemak bebas ke dalam sirluklasi portal dan merangsang produksi partikel VLDL yang banyak sehingga berdampak pada meningkatkan kadar kolesterol LDL dan menurunkan kadar kolesterol HDL ${ }^{1,15,16}$.

Asupan serat sebelum dan selama intervensi pada ketiga kelompok tergolong kurang, rata-rata asupan ketiga kelompok sebesar 11,9 g. Kebutuhan asupan serat pada orang dewasa untuk menanggulangi kolesterol telah ditetapkan oleh Food and Drug Administration (FDA) yaitu sebanyak minimal $10 \%$ bahan sumber serat dari total diet ${ }^{17}$. Konsumi serat yang dianjurkan sebanyak 25-35 g/hari. Serat dapat menurunkan kadar kolesterol darah dengan mengikat asam empedu sehingga meningkatkan pengeluaran asam empedu pada feses ${ }^{1,18}$.

Pemberian snack bar diberikan sebanyak 40 g karena kalori yang terkandung persajian sesuai dengan kebutuhan kalori untuk makanan selingan $( \pm 10 \%$ dari kebutuhan kalori total $)$ yang diberikan sebanyak dua kali dalam sehari ${ }^{1}$. Pemberian snack bar kedelai kuning dan snack bar kedelai hitam berpengaruh terhadap kadar kolesterol LDL tetapi tidak terhadap kadar kolesterol HDL. Terdapat penurunan kadar kolesterol LDL pada kelompok yang diberikan snack bar kedelai hitam dan snack bar kedelai kuning berturut-turut sebanyak $6,47 \%$ dan 13,02 $\%$. Secara statistik penurunan kolesterol LDL yang bermakna terjadi pada kelompok perlakuan 2 dengan penurunan $19,73 \mathrm{mg}$ atau sebesar $13,02 \%$ $(\mathrm{p}=0,049)$. Sedangkan kelompok kontrol mengalami kenaikan sebesar 2,25\% (3,77 mg). Peningkatan kadar kolesterol HDL hanya terjadi pada kelompok perlakuan 1 atau snack bar kedelai hitam sebesar 0,22 mg. Hal tersebut kemungkinan disebabkan karena penambahan asupan snack bar ubi jalar pada kelompok perlakuan yang mengandung isoflavon dan antosianin dibandingkan kelompok kontrol yang tidak diberikan snack bar.

Kedelai mengandung isoflavon yang strukturnya mirip dengan hormon estrogen yang akan berinteraksi dengan reseptor estrogen sehingga dapat menurunkan kadar kolesterol melalui mekanisme yang sama dengan meregulasi liposis, lipogenesis dan adipogenesis. Isoflavon menstimulasi aktivitas Sterol Regulatory Element Binding Protein (SERBP-2) yang menghambat aktivitas enzim HMG-KoA reduktase sehingga pembentukan mevalonat terhambat dan sintesis kolesterol menurun. Selain itu isoflavon dapat meningkatkan aktivitas up regulating reseptor LDL yang akan meningkatkan pembersihan LDL dari peredaran darah sehingga jumlah kolesterol LDL dalam darah akan berkurang. Isoflavon juga berperan sebagai antioksidan dengan mencegah proses oksidasi LDL dan berperan dalam menginduksi Peroxisome Proliferator Activated Receptor (PPAR) yang bekerja dalam makrofag dengan menghambat proses angiogenesis ${ }^{6,8,14}$.

Snack bar selain mengandung isoflavon juga mengandung antosianin yang berasal dari kedelai hitam dan ubi jalar ungu. Antosianin merupakan senyawa fenolik yang memberikan pigment berwarna merah, biru, dan ungu pada tanaman dan bersifat larut air ${ }^{12,19}$. Antosianin pada kedelai hitam, cyanidin-3-glucoside, terdapat pada kulit kedelai, sedangkan pada ubi jalar ungu, 3caffeoyl sophoroside-5-glucoside yang terdapat pada seluruh bagian ubi jalar ${ }^{9,11,19}$. Antosianin dapat menurunkan kadar kolesterol LDL dengan mengaktifkan jalur adenosine-monophosphate protein kinase (AMPK) yang menghambat regulasi 
enzim HMG-KoA reduktase dalam sintesis kolesterol dan menghambat Asetil-KoA Karboksilase (ACC) sehingga menurunkan esterifikasi kolesterol pada usus dan hati. Jika pembentukan kolesterol terhambat maka VLDL tidak akan dihidrolis dan akan menekan LDL dalam darah ${ }^{20}$.

Tabel 4. Kandungan Gizi Snack Bar Kedelai per sajian (40 g)

\begin{tabular}{lcc}
\hline & Snack bar kedelai kuning & Snack bar kedelai hitam \\
\hline Energi (kkal) & 131,3 & 134,6 \\
Air (g) & 9,8 & 10,03 \\
Protein (g) & 5,3 & 6,5 \\
Lemak (g) & 3 & 3,6 \\
Karbohidrat (g) & 21 & 18,8 \\
Serat (g) & 1,3 & 1,13 \\
Antosianin (mg) & 8,01 & 7,72 \\
Isoflavon (mg) & 496 & 404 \\
\hline
\end{tabular}

Sumber: hasil uji proximat, antosianin, dan isoflavon Universitas Muhammadiyah

Penurunan kolesterol LDL terjadi lebih besar pada kelompok perlakuan snack bar kedelai kuning dibandingkan dengan penurunan kadar kolesterol pada kelompok perlakuan snack bar kedelai hitam. Hal ini dikarenakan kandungan isoflavon dan antosianin yang lebih banyak pada snack bar kedelai kuning dibandingkan dengan snack bar kedelai hitam. Pembuatan snack bar melalui proses perendaman kedelai, pencucian, pengukusan, dan pemanggangan. Proses tersebut menjadikan isoflavon dan antosianin yang terdapat pada kedelai dan ubi ungu mengalami perubahan nilai gizi ${ }^{10}$. Kandungan profil isoflavon pada kedelai kuning dan kedelai hitam mengalami penyusutan tetapi phenolic acid pada pada kedelai kuning meningkat selama pemanasan sedangkan pada kedelai hitam mengalami penurunan ${ }^{21,22}$. Penyusutan isoflavon dan antosianin terjadi lebih besar pada snack bar kedelai hitam menyebabkan efeknya tidak seoptimal snack bar kedelai kuning dalam menurunkan kadar kolesterol LDL. Selain itu kandungan serat yang lebih banyak terdapat pada snack bar kedelai kuning.

Tidak ada perubahan atau kenaikan HDL yang bermakna setelah diberikan intervensi snack bar kedelai kuning maupun snack bar kedelai hitam. Peningkatan kadar HDL terjadi pada kelompok snack bar kedelai hitam sebesar 0,22 mg. Penurunan kadar kolesterol HDL pada kelompok intervensi dengan snack bar kedelai kuning dipengaruhi oleh asupan kolesterol dan lemak subyek yang meningkat selama intervensi serta status gizi subyek yang mengalami obesitas 1 . Meningkatnya asupan lemak juga dipengaruhi oleh asupan kedelai dari snack bar. Kedelai mengandung PUFA yang dapat berpengaruh terhadap kadar kolesterol $\mathrm{HDL}^{4}$. Asupan PUFA dapat menurunkan kolesterol HDL dengan menghambat sintesis apolipoprotein A-1 yang merupakan protein utama lipoprotein pada pembentukan $\mathrm{HDL}^{4,23}$. Obesitas berpengaruh terhadap menurunnya kadar kolesterol HDL karena menyebabkan peningkatan penyerapan $\mathrm{HDL}_{2}$ oleh sel adiposit dan peningkatan katabolisme apolipoprotein A-I pada partikel HDL sehingga kadar kolesterol HDL rendah ${ }^{24}$.

\section{SIMPULAN}

Terdapat penurunan bermakna kadar kolesterol LDL sebesar 19,73 mg (13,02\%) pada kelompok yang diberikan snack bar kedelai kuning. Kelompok yang diberikan snack bar kedelai hitam terdapat penurunan sebesar 10,28 mg $(6,47 \%)$, sedangkan pada kelompok kontrol terdapat peningkatan kadar kolesterol LDL sebesar 3,77 mg. Peningkatan kadar kolesterol HDL terjadi pada kelompok yang diberikan snack bar kedelai hitam sebesar 0,22 mg tetapi tidak pada kelompok yang diberikan snack bar kedelai kuning setelah diberikan intervensi 80 gr snack barl hari selama 28 hari.

\section{SARAN}

Modifikasi selingan makan bagi penderita hiperkolesterolemia berbasis ubi jalar ungu dan kedelai kuning dapat menjadi salah satu pilihan untuk menurunkan kadar kolesterol LDL .

\section{DAFTAR PUSTAKA}

1. Krummel DA. Medical Nutrition Therapy in Cardiovascular Disease. In Mahan LK, Escottstump S. Krause's food, Nutrition, and Diet 
Therapy. 13th ed. Philadelphia: WB Saunders Company;2012.

2. Veghari G, Mehdi S. Obesity and risk of hypercholesterolemia in Iranian northern adults. ARYA Atheroscler.2013; Vol 9: 1.

3. Expert Panel on Detection, Evaluation, and Treatment of High Blood Cholesterol in Adults. Executive Summary of the Third Report of the National Cholesterol Education Program (NCEP) Expert Panel on Detection, Evaluation, and Treatment of High Blood Cholesterol in Adults (Adult Treatment Panel III). JAMA.2001; 285:2486-2497.

4. Sacks FM, Alice L,Linda VH. Soy Protein, Isoflavones, and Cardiovascular Health: A Summary of a Statement for Professionals From the American Heart Association Nutrition Committee. Arterioscler Thromb Vasc Biol.2006;26:1689-1692.

5. Jenkins DJ, Cyril WC, Chung-JCJ. Effect of highand low isoflavone soyfood on blood lipids, oxidized LDL, homocysteine, and blood pressure in hyperlipidemic men and women. Am J Clin Nutr.2002;76:365-72.

6. Aparicio IM, Redondo C, Zapata R. Soybean, a promising health source. Nutr Hosp.2008;23:305312.

7. Kenneth RD,Setchell. Soy Isoflavones-Benefits and Risks from Nature's Selective Estrogen Receptor Modulators (SERMs). Journal of the American College of Nutrition.2001; Vol. 20(5): 354S-362S.

8. Larkin T, Price WE, Astheimer L. The key importance of soy isoflavone bioavailability to understanding health benefits. Critical Reviews in Food Science and Nutrition.2008; 48 (6):538-552.

9. Byun JS, Young SH, Sang SL. The effects of Yellow Soybean,Black Soybean, and Sword Bean on Lipid Levels and Oxidative Stress in Ovariectomized Rats. Int. J. Vitam. Nutr. Res.2010; 80 (2): 97 - 106.

10. Takahashi R, Kiyose C, Mimoyama Y, Ohsuzu F. Antioxidant activities of black and yellow soybeans againts low density lipoprotein oxidation. J.Agric Food Chem. 2005.53;4578-82.

11. Bhuiyan MIQ, Joo YK, Tae JH, Seong YK. Anthocyanins Extracted from Black Soybean Seed Coat Protect Primary Cortical Neurons against in Vitro Ischemia.Regular Article.Biol. Pharm. Bull.2011;35(7): 999-1008.

12. Giuseppe M. Anthocyanins and heart health. Pacific Agri-Food Research Centre, Agriculture and Agri-Food Canada. 2007; Vol. 43: 369-3744: 369-374.

13. Jawi IM, Ketut B. Ekstrak Air Umbi Ubi Jalar Ungu Menurunkan Total Kolesterol serta Meningkatkan Total Antioksidan Darah Kelinci. Jurnal Veteriner.2011; 12 (2): 120-125.
14. Zhan S, Ho SC. Meta-analysis of the effects of soy protein containing isoflavones on the lipid profile. Am J Clin Nutr.2005; 81:397-408.

15. Delavar MA, Lye MS, Hassan STBS. Physical Activity, Nutrition, and Dyslipidemia in MiddleAged Women. Iranian J Publ Health.2011; Vol. 40(4): p.89-98.

16. Panagiotakos DB, Christos $\mathrm{P}$, Yannis S. Abdominal obesity, blood glucose and apolipoprotein B levels are the best predictors of the incidence of hypercholesterolemia (20012006) among healthy adults: the ATTICA Study. Biomed Central.2008.

17. FDA. Health Claim: Fruit, Vegetable and Grain Product that Contain Fiber, Particularly Soluble Fiber, and Risk of Coronary Heart Disease. US Government Printing Office via GPO access. 1999;2(21):130-3.

18. Eshak ES, Hiroyasu I, Chigusa D. Dietary Fiber Intake Is Associated with Reduced Risk of Mortality from Cardiovascular Disease among Japanese Men and Women. J. Nutr. 2010; 140: 1445-1453.

19. Liu R. Potential Synergy of Phytochemicals in Cancer Prevention: Mechanism of Action. The Journal of Nutrition. 2004 ; 134:3479S-3485S.

20. Yong PL, Jae HC, Eun HH, Hyung GK, Ji HW, Kyung OJ, et al. Purple sweet potato anthocyanin attenuate hepatic lipid accumulation, through activating adenosine monophosphate-activated protein konase in human $\mathrm{HpG} 2$ cell and obese mice. NRJournal.2011;31:896-906.

21. Xu B, Sam KCC. Total Phenolics, Phenolic Acids, Isoflavones, and Anthocyanins and Antioxidant Properties of Yellow and Black Soybeans As Affected by Thermal Processing. J. Agric. Food Chem.2008;56 (16):p.7165-7175.

22. Dan Wang, Yue Ma, Chao Zhang, Xiaoyan Zhao. Thermal characterization of the anthocyanins from black soybean (Glycine max L.) exposed to thermogravimetry. LWT - Food Science and Technology. 2011.

23. Gropper SS, Jack LS, and James LG. Lipid. Advanced Nutritin and Human Metabolism 5th ed. USA 2009;5 p.131-176.

24. Rashid S, Jacques G. Effect of obesity on highdensity lipoprotein metabolism. Obesity. 2007; 15:2875-2888. 